\title{
Pregnancy diagnosis in cattle by a rapid and highly reliable method for progesterone determination in milk
}

\author{
P. Inaudi*, M. Bacigalupo $†$, C. Monittola, G. Lugaro $\dagger$ and A. R. \\ Genazzani
}

\begin{abstract}
Cattedra di Patologia Ostetrica e Ginecologica, Università degli Studi di Cagliari, and $\uparrow$ Istituto di Chimica degli Ormoni del C.N.R., Milano, Italy
\end{abstract}

\begin{abstract}
Summary. A highly reliable technique for the determination of progesterone in milk has been developed, and its application to pregnancy diagnosis in cows is reported. The method is characterized by an activated charcoal treatment of the samples, extraction of the absorbed progesterone by an organic solvent, followed by RIA. The application of the method to pregnancy diagnosis, 21-23 days after artificial insemination, shows that $5 \mathrm{ng} / \mathrm{ml}$ is the most useful value to discriminate between pregnant and non-pregnant animals, with greatest precision on the 21 st day, in that $93.5 \%$ of pregnant and $100 \%$ of non-pregnant animals were correctly diagnosed.
\end{abstract}

\section{Introduction}

It is generally accepted that progesterone is one of the chief hormonal characteristics used in the evaluation of reproductive function in pregnant and non-pregnant cattle (Donaldson, Bassett \& Thorburn, 1970; Glencross, Munro, Senior \& Pope, 1973; Inaudi et al., 1980).

The evaluation of progesterone levels in blood and milk, 20-25 days after insemination, has been used for the diagnosis of pregnancy (Robertson \& Sarda, 1971; Gadsby, Heap, Henville \& Laing, 1974; Pope, Majzlik, Ball \& Leaver, 1976; Bulman \& Lamming, 1976; Hoffmann, Günzler, Hamburger \& Schmidt, 1976; Heap, Holdsworth, Gadsby, Laing \& Walters, 1976; Pennington, Spahr \& Lodge, 1976a; Holness, Ellison \& Wilkins, 1977; Erb, Chew \& Keller, 1977), but determinations in milk offer considerable advantages because milk is easier to collect than blood. Various methods have been described for the assay of progesterone in milk, either directly in small amounts of milk (Gadsby et al., 1974; Bulman \& Lamming, 1976; Heap et al., 1976; Dobson \& Fitzpatrick, 1976; Allen, Redshaw \& Holdsworth, 1980) or after extraction with petroleum ether (Schiavo, Matuszczak, Oltanacu \& Foote, 1975; Pennington et al., 1976a) or petroleum ether and methanol (Hoffmann et al., 1976), but the existence of non-specific interference, the high solubility of progesterone in fat and the effect of variations in fat content on the amount of progesterone determined in different milk samples (Pope et al., 1976) give low precision and accuracy of the assays (Schiavo et al., 1975; Heap et al., 1976). There is clearly a need for a method of progesterone measurement in milk which is simple, rapid and reliable, particularly for the absolute values, and the present paper describes such an assay.

\section{Materials and Methods}

The solvents used (Merck, Darmstadt, Germany) were of very high purity and suitable for use without further purification. A $0.1 \mathrm{M}$-Tris- $\mathrm{HCl}$ buffer, $\mathrm{pH} 7.4$ (Buffer A) containing gelatin

\footnotetext{
* Present address: Cattedra di Patologia Ostetrica, Istituto Clinica Ostetrica, Via Ospedale, 09100 Cagliari, Italy.
} 
$(0.1 \%$, BDH, U.K.) (Buffer B) or human gamma-globulins $(0.5 \mu \mathrm{g} / \mathrm{ml}$; Sclavo, Siena, Italy) (Buffer C) was used according to the specific purpose.

The progesterone standard was obtained from Wistar (Milan, Italy), dissolved in absolute ethanol and stored at $-20^{\circ} \mathrm{C} .\left(1,2,6,7-{ }^{3} \mathrm{H}\right]$ Progesterone (sp. act. $100 \mathrm{Ci} / \mathrm{mmol} ; \mathrm{NEN}$, Boston, U.S.A.) was diluted with benzene to approximately 100000 c.p.m. $/ \mathrm{ml}$ and stored at $4{ }^{\circ} \mathrm{C}$. ${ }^{125}$ I-Labelled progesterone (sp. act. $1522 \mathrm{Ci} / \mathrm{mmol}$ ) was obtained from SORIN (Saluggia, Vercelli, Italy) and used in several experiments. The specific antibody used was obtained in rabbits immunized with progesterone-11 $\alpha$ hemisuccinate-BSA and used at a 1:25000 working dilution (SORIN). Cross-reactions were considered to be as stated by the manufacturer, i.e. progesterone $100 \%$, cortisone $0.65 \%$, testosterone $0.5 \%, 17 \alpha$-hydroxyprogesterone $0.37 \%$, 20a-progesterone $0.20 \%, 20 \beta$-progesterone $0.28 \%, \Delta_{5}$-pregnenolone $0.05 \%$, androstenedione $0.04 \%$, oestradiol $0.01 \%, 3 \beta, 17 \alpha$-hydroxyprogesterone $0.01 \%$, androsterone $<0.01 \%$, cortisol $<0.004 \%$, epitestosterone $<0.0001 \%$. The dextran-coated charcoal solution was obtained by mixing $20 \mathrm{mg}$ dextran T-70 (Pharmacia, Uppsala, Sweden) and $200 \mathrm{mg}$ charcoal (Norit A, Heidelberg, Germany) with $60 \mathrm{ml}$ Buffer B. Milk samples were collected manually from clinically normal Friesian cows in a well-managed herd. The samples were a fraction of the total volume of milk collected at $16: 00 \mathrm{~h}$, and stored at $-20^{\circ} \mathrm{C}$ without preservatives until time of use.

\section{Present method}

A sample of milk $(0.1 \mathrm{ml})$ was placed in a glass tube (RIA tubes, $11 \times 70 \mathrm{~mm}$ ) diluted to $0.5 \mathrm{ml}$ with Buffer $\mathrm{B}$ and $0.1 \mathrm{ml}$ dextran-coated charcoal was added. The sealed tubes were placed in a rotary mixer for $30 \mathrm{~min}$ and then centrifuged at $800 \mathrm{~g}$ for $2 \mathrm{~min}$. The aqueous phase and lipids present on the surface were removed by suction using a water pump and the remaining charcoal pellet was dispersed by gentle manual shaking. One of two procedures was then used.

In Procedure 1, $1 \mathrm{ml}$ absolute ethanol was added to all the manually shaken tubes which were sealed and placed in a rotary mixer for $30 \mathrm{~min}$ and then centrifuged for $10 \mathrm{~min}$ at $1500-2000 \mathrm{~g}$. Two aliquots of ethanol $(2 \times 0.3 \mathrm{ml})$ were transferred to the tubes for RIA. All tubes were then brought to $37^{\circ} \mathrm{C}$ and dried in a vacuum. The dried samples were re-dissolved with $0.3 \mathrm{ml}$ Buffer A per tube for $1 \mathrm{~h}$ at $37^{\circ} \mathrm{C}$, mixing twice during this period, and were then ready for RIA.

In Procedure 2,1 ml acetone was added to all the manually shaken tubes which were sealed and placed in the rotary mixer for $30 \mathrm{~min}$ and then centrifuged for $10 \mathrm{~min}$ at $1500-2000 \mathrm{~g}$. All the acetone was decanted and the residues were dried at $37^{\circ} \mathrm{C}$. The dried fraction was then dissolved in $1 \mathrm{ml} \mathrm{Buffer} \mathrm{A}$ at $37^{\circ} \mathrm{C}$ for $1 \mathrm{~h}$, mixing twice during this period. Finally, two aliquots $(0.3 \mathrm{ml})$ of buffer were transferred to the assay tubes for RIA.

The RIA was carried out using tritiated progesterone (6000 d.p.m./tube) which was added together with antibody, followed by overnight incubation at $4{ }^{\circ} \mathrm{C}$ and then separation with dextran-coated charcoal. The tritiated hormone and the antibody were prepared in Buffer $\mathrm{C}$. The standard curve ranged between 12.5 and $800 \mathrm{pg}$. The supernatant was mixed with a scintillation liquid (Pico Fluor 30, Packard) and counted in a Packard PRIAS PL counter. A few samples were assayed in parallel, in a system using ${ }^{125} \mathrm{I}$-labelled progesterone; the incubation times were $30 \mathrm{~min}$ at $37^{\circ} \mathrm{C}$ and $2 \mathrm{~h}$ at $4^{\circ} \mathrm{C}$.

\section{Direct radioimmunoassay}

The method of Gadsby et al. (1974) was used to measure progesterone in unextracted, diluted milk samples. $0.1 \mathrm{ml}$ milk diluted 1:10 with Buffer A was preincubated for 30 min at $20^{\circ} \mathrm{C}$ with $0.3 \mathrm{ml}$ antibody at the same working dilution as described above. After the addition of $0.1 \mathrm{ml}$ Buffer $\mathrm{C}$ containing approximately $10^{4}$ d.p.m. of tritiated progesterone, an overnight 
incubation at $4^{\circ} \mathrm{C}$ and separation with dextran-coated charcoal were performed. The standard curve was prepared with known concentrations of progesterone (10-500 pg) in a buffer to which $10 \mu \mathrm{l}$ milk from an ovariectomized cow were also added.

\section{Results}

\section{Milk extraction}

Various experiments were performed to optimize the method. The first experiment was aimed at establishing the optimal ratio of milk to dextran-coated charcoal to give the maximal recovery of hormone. Constant aliquots of milk containing a small amount of labelled progesterone were treated (after an adequate equilibration time) with different concentrations of dextran-charcoal $(0 \cdot 166-1 \mathrm{mg} /$ tube). In a kinetic study, the rotary mixer (see 'Methods') was stopped every $5 \mathrm{~min}$ during the first $30 \mathrm{~min}$ and then every $10 \mathrm{~min}$ for a further $30 \mathrm{~min}$. At each interruption, one tube was removed for each different dextran-charcoal concentration. These tubes were immediately centrifuged and the supernatant was decanted into plastic vials and counted. The results (Text-fig. 1a) show that there was increased absorption of progesterone with increasing concentrations of charcoal. The dextran-charcoal pellets were treated with $1 \mathrm{ml}$ absolute ethanol and a further kinetic study of progesterone re-extraction was performed on the rotary mixer as described above.

The maximum amount of labelled hormone extracted by the solvent (Text-fig. 1b) corresponded to a concentration of $0.333 \mathrm{mg}$ charcoal/tube. At this concentration, $80 \%$ progesterone was absorbed after only $5 \mathrm{~min}$ and $90 \%$ after $40 \mathrm{~min}$ of treatment (Text-fig. 1a). It was also observed that the ethanol extraction gave $45 \%$ recovery after $30 \mathrm{~min}$, increasing to $50 \%$ at $60 \mathrm{~min}$ (Text-fig. $1 \mathrm{~b}$ ).

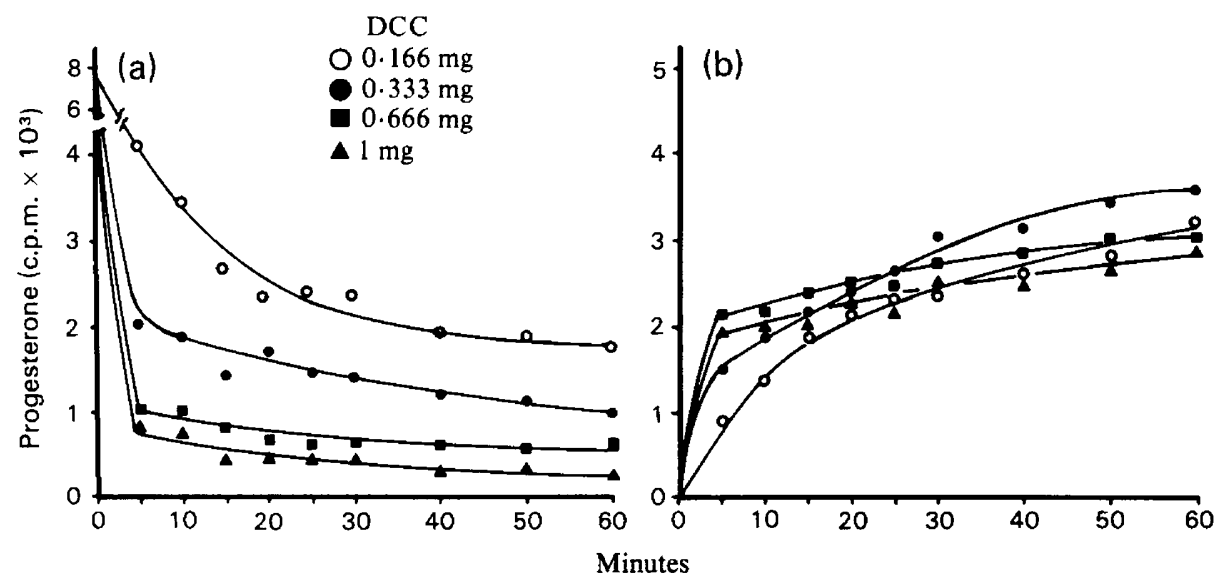

Text-fig. 1. Amounts of progesterone (a) absorbed over $1 \mathrm{~h}$ from $0.1 \mathrm{ml}$ milk with different concentrations of dextran-coated charcoal (DCC) and (b) re-extracted with $1 \mathrm{ml}$ absolute ethanol.

Two further experiments were required to obtain the same conditions for each tube, after absorption and before re-extraction, for the various time intervals. The absorption of progesterone at various times was evaluated by (1) using $0.333 \mathrm{mg}$ dextran-charcoal/tube followed by re-extraction with ethanol for $1 \mathrm{~h}$ in all samples (Text-fig. 2a), and (2) by using $0.333 \mathrm{mg}$ dextran-charcoal/tube for $1 \mathrm{~h}$ followed by exposure to ethanol for various times 
(Text-fig. 2b). Plateau values were reached after $30 \mathrm{~min}$ of exposure to dextran-charcoal (Text-fig. 2a) and after $15 \mathrm{~min}$ of exposure to ethanol (Text-fig. 2b).

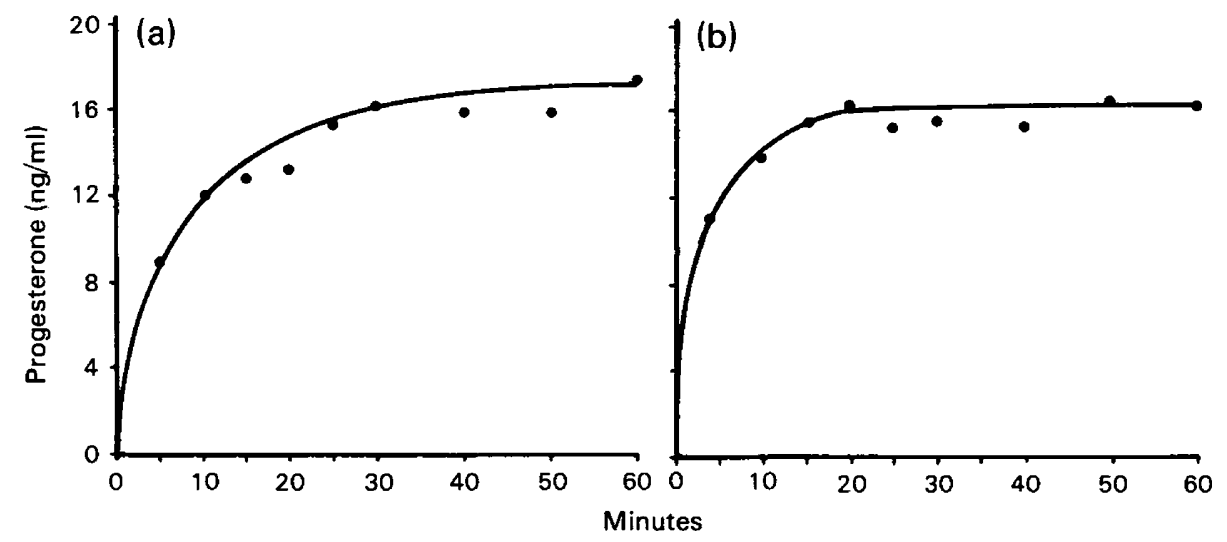

Text-fig. 2. Absorption (a) and re-extraction (b) of endogenous progesterone from $0.1 \mathrm{ml}$ milk and with $0.333 \mathrm{mg}$ dextran-coated charcoal.

When the absolute concentration of milk was varied from 0.1 to $0.3 \mathrm{ml}$ but the milk:dextran-charcoal ratio was held constant (i.e. $0.1 \mathrm{ml}$ milk: $0.333 \mathrm{mg}$ charcoal), the recovery remained the same $(48 \cdot 1 \pm 1 \cdot 8 \% ; n=6)$ (Text-fig. 3 ).
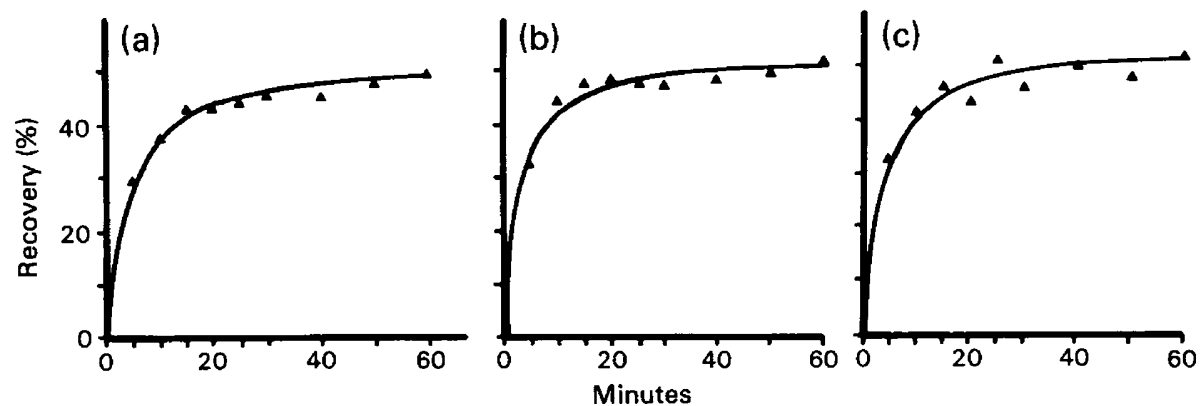

Text-fig. 3. Evaluation of the stability of progesterone recovery by using different amounts of milk and dextran-coated charcoal at a constant ratio: (a) $0.1 \mathrm{ml}$ milk with $0.333 \mathrm{mg}$ charcoal, (b) $0.2 \mathrm{ml}$ milk and $0.666 \mathrm{mg}$ charcoal and (c) $0.3 \mathrm{ml}$ milk with $1 \mathrm{mg}$ charcoal.

To check the effect of the solvent, a sample of the same milk pool containing $\left[{ }^{3} \mathrm{H}\right.$ ]progesterone was treated with $0.333 \mathrm{mg}$ dextran-charcoal/tube $(n=12)$ and extracted with $1 \mathrm{ml}$ of different organic solvents. The percentage recoveries were as follows: methanol, $49.0 \pm$ $4 \cdot 2$; cyclohexane, $17 \cdot 6 \pm 6 \cdot 8$; ethylacetate, $11 \cdot 6 \pm 3 \cdot 3$; iso-octane, $4.4 \pm 3 \cdot 9 ; N$-hexane, $4 \cdot 3 \pm$ $3 \cdot 2$; diethylether, $6 \cdot 6 \pm 5 \cdot 1$; ethanol, $48 \cdot 8 \pm 3 \cdot 2$; acetone, $53 \cdot 2 \pm 4 \cdot 0$.

A highly significant correlation was found when the results obtained using absolute ethanol (Procedure 1) and acetone (Procedure 2) as extractor solvents were compared. The equation of the regression line calculated on 50 different milk samples was $y=0.135+1.034 x, r=0.9925$. 


\section{Reliability parameters for RIA}

Different tests were performed to evaluate the accuracy and precision of the method. Additions of $4,2,1$ and $0.5 \mathrm{ng}$ progesterone were made to a milk pool containing $6.88 \pm 0.29$ (s.d.) ng progesterone $/ \mathrm{ml}$. After equilibration of the system $\left(1 \mathrm{~h}\right.$ at $\left.20^{\circ} \mathrm{C}\right)$, extractions of ten $0 \cdot 1-\mathrm{ml}$ aliquots of each milk pool were performed, and the extracts were assayed by RIA. The results, corrected for the extraction procedure losses, were respectively $10.6 \pm 0.93,9.2 \pm 0.46$, $8.1 \pm 0.56$ and $7.1 \pm 0.34 \mathrm{ng} / \mathrm{ml}$. To check the accuracy of the method, increasing volumes of two different milk samples were assayed; the respective regression lines were $y=3.3478+$ $4.7019 x(r=0.9994)$ and $y=3.0695+1.7820 x(r=0.9995)$, indicating a parallel response and the absence of interfering factors. The buffer blank, which was evaluated in the course of different milk assays, was always undetectable.

The RIA sensitivity, defined as the smallest amount of pure standard hormone which significantly differs from zero, was evaluated as described by Inaudi \& Genazzani (1980) and was $12 \mathrm{pg} /$ tube.

The within- and between-assay variations were $4.3 \%(n=10)$ and $7.6 \%(n=8)$, respectively.

\section{${ }^{125}$ I-Labelled progesterone}

A comparison of values measured by the ${ }^{3} \mathrm{H}$ and ${ }^{125} \mathrm{I}$ methods (Text-fig. 4) showed a
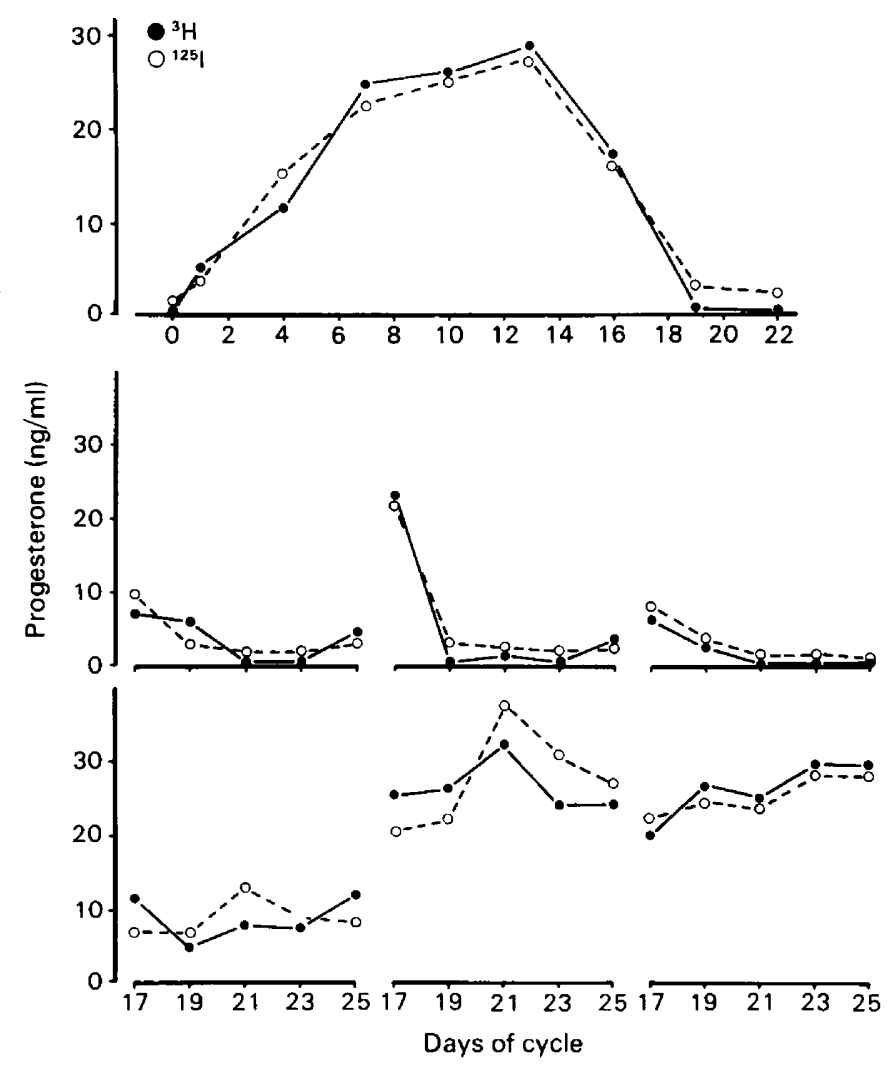

Text-fig. 4. Comparison of milk progesterone values in several samples assayed by RIA using progesterone labelled with ${ }^{3} \mathrm{H}$ or ${ }^{125} \mathrm{I}$. 
significant correlation $(n=39 ; r=0.9569 ; P<0.001)$ for the progesterone concentrations determined by the two methods in the same milk samples.

\section{Direct RIA}

To assess the accuracy of the direct RIA, two different experiments were performed. Unlabelled progesterone, 500,125 and $31.2 \mathrm{pg}$, was added in triplicate to several $0.1 \mathrm{ml}$ aliquots of milk pool diluted 1:10 in Buffer A and equilibrated for $1 \mathrm{~h}$ at $20^{\circ} \mathrm{C}$. The results (Text-fig. 5) demonstrated the lack of precision and accuracy with over-estimation of low values and under-estimation of high values, and a great variability between the samples containing the same concentrations of added progesterone. In the second experiment, progesterone was measured in $50,25,12.5$ and $6.2 \mu \mathrm{l}$ samples of two milk pools. There was little or no response to dilution (Text-fig. 5), giving values always at the limit of the method's sensitivity. Progesterone concentrations determined in the same pools of milk after dextran-charcoal and ethanol extraction gave $2.89 \pm 0.9(n=19)$ and $6.88 \pm 0.29(n=10)(\mathrm{ng} / \mathrm{ml})$.

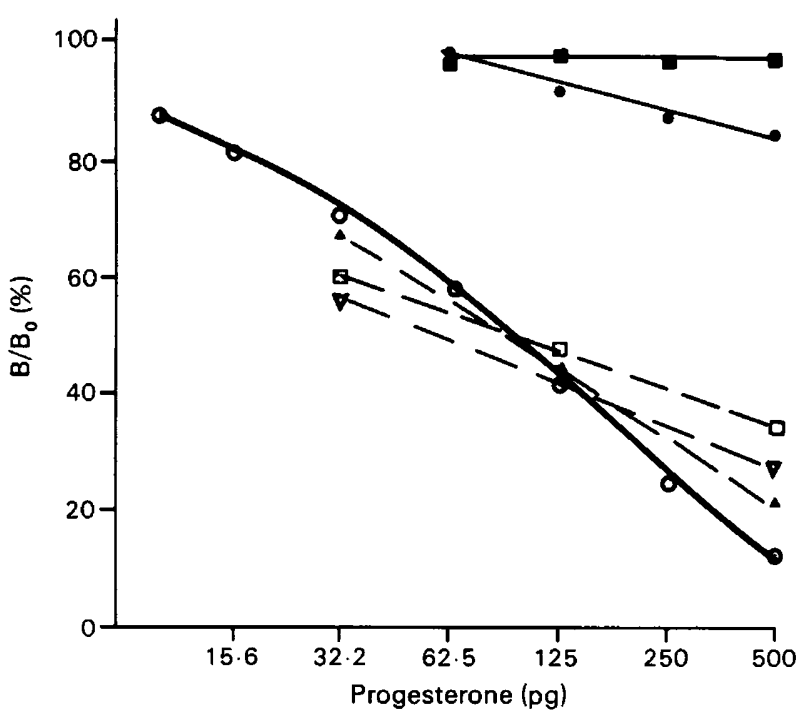

Text-fig. 5. Direct RIA of milk progesterone content: evaluation of the response to the addition of different amounts of unlabelled progesterone to a milk pool (broken lines) and response to dilution of the same milk pool (continuous lines).

\section{Early diagnosis in pregnancy}

To evaluate the practical application of the present method to pregnancy diagnosis, milk samples were collected from 100 cows on Days 17, 19,21, 23 and 24 after artificial insemination.

Clinical observations indicated that 46 animals became pregnant, while 54 remained non-pregnant. The pattern of progesterone concentrations in the milk samples (Text-fig. 6) suggests that a value of $5 \mathrm{ng}$ progesterone/ml milk is the most useful limit to discriminate pregnant (higher values) from non-pregnant animals (lower values). The success of using this value for diagnosis is indicated in Table 1. 


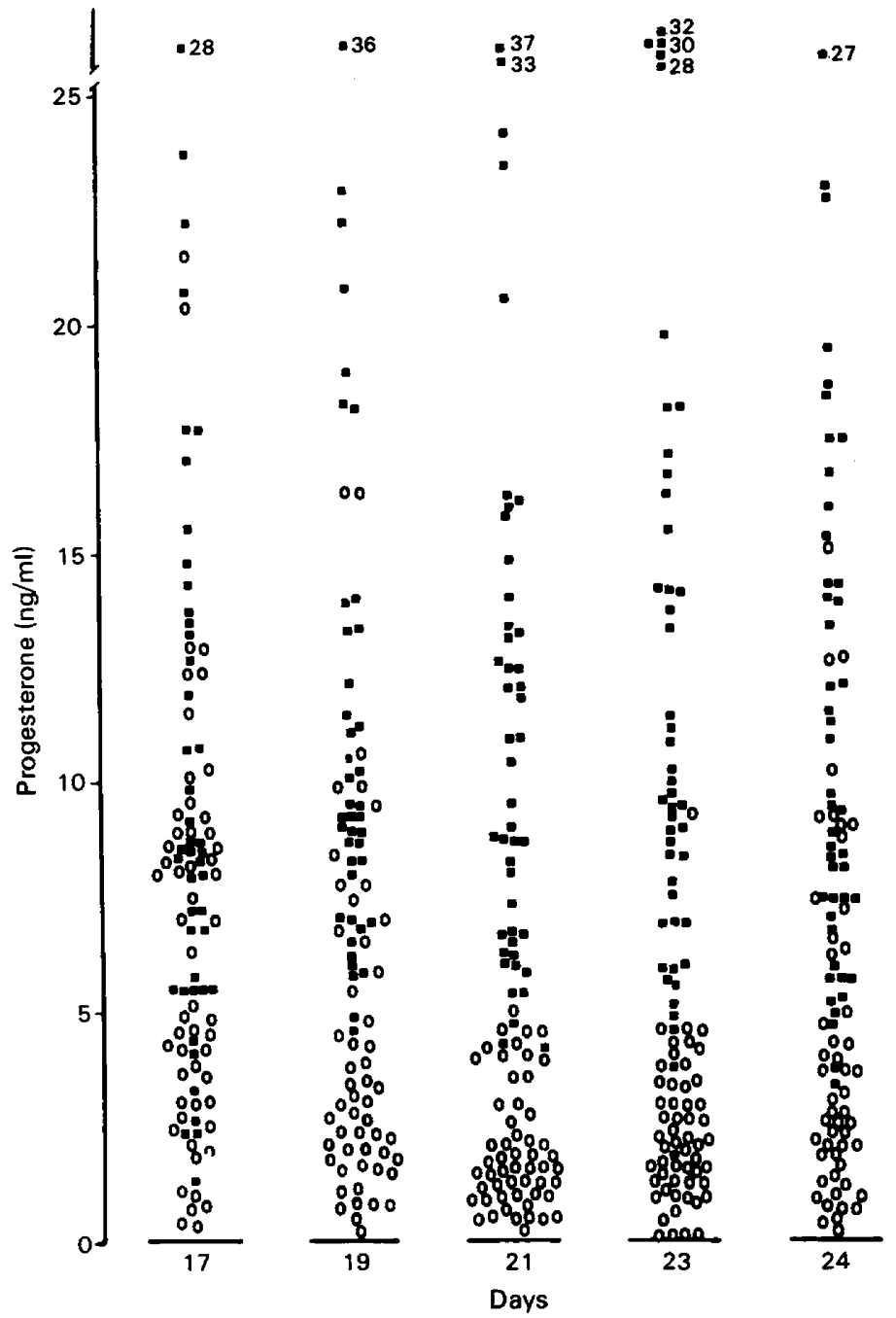

Text-fig. 6. Milk progesterone concentrations in pregnant $(\square)$ and non-pregnant $(O)$ animals considered in the present study.

Table 1. Diagnosis of pregnancy in cattle by determination of progesterone concentration in milk samples

\begin{tabular}{cccccc}
\hline & \multicolumn{2}{c}{$\begin{array}{c}\text { Pregnant } \\
\text { cows }(\mathbf{N}=46)\end{array}$} & & \multicolumn{2}{c}{$\begin{array}{c}\text { Non-pregnant } \\
\text { cows }(\mathbf{N}=54)\end{array}$} \\
\cline { 2 - 3 } \cline { 5 - 6 } $\begin{array}{c}\text { Days after } \\
\text { A.I. }\end{array}$ & No. & $\%$ & & No. & $\%$ \\
\hline 17 & 39 & 84.8 & & 26 & $48 \cdot 1$ \\
19 & 39 & 84.8 & & 37 & 68.6 \\
21 & 43 & 93.5 & & 54 & 100 \\
23 & 42 & 91.3 & & 53 & 98.1 \\
24 & 42 & 91.3 & & 40 & 74.0 \\
\hline
\end{tabular}

The classification of pregnant and non-pregnant cows was based on trans-rectal palpation, 60 days after artificial insemination. 


\section{Discussion}

The most important problem in the determination of progesterone in milk is the presence of substantial concentrations of lipids which interfere in the radioimmunoassay. The previously reported methods utilize extraction procedures which are very lengthy, taking up to a maximum of $72 \mathrm{~h}$ (Schiavo et al., 1975). A direct RIA has the undoubted advantage of time and cost but the drawback of limited precision as shown by an intra-assay variation of about $20 \%$, and by a significant over-estimation of low levels and under-estimation of high progesterone levels (Heap et al., 1976). A further disadvantage of this method lies in the fact that milk sample with a low progesterone content which must be added to the standard curve to obtain the same incubation conditions as those of the unknown samples can represent a further source of error, affecting the lowest concentration of the standard curve (Pennington et al., 1976b).

Progesterone measurements by a competitive protein-binding assay also gave a significant over-estimation at the lowest concentrations (Schiavo et al., 1975).

In our experience, the above mentioned methods have shown very poor accuracy for determination of the different amounts of progesterone added to the same milk pool (cold recovery test), and of progesterone in different amounts of the same milk pool (parallelism test) (Text-fig. 5). Dextran-coated charcoal treatment of the milk sample, as described in this paper, presents several positive features. First, the elimination of lipids is rapid (30 $\mathrm{min})$ and complete, judging by the fact that they are undetectable in the sample before RIA, as measured by a kit for Total Lipids purchased from Carlo Erba (Milan, Italy). The RIA itself is performed without modifications of the standardized technique for the determination of progesterone in human plasma (Abraham, Swerdloff, Tulchinsky \& Odell, 1971). In this way, further possible sources of error such as the addition of an amount of milk to the standard curve or the use of large amounts of tritiated progesterone (Heap et al., 1976; Ginther, Nuti, Garcia, Wentworth \& Tyler, 1976; Pennington et al., 1976a, b) at low specific activity, are avoided. Moreover, up to $90-100$ samples can be tested simultaneously by a single technician and the results are ready in $24-30 \mathrm{~h}$. With respect to its application to pregnancy diagnosis, the great precision in the absolute value allows the elimination of the "questionable range" (Pennington $e t$ al., 1976a, b; Dobson \& Fitzpatrick, 1976), and a single discriminating value $(5 \mathrm{ng} / \mathrm{ml}$ in our experiments) is sufficient for the diagnosis of pregnancy.

Maximum accuracy in pregnancy diagnosis was obtained 21 days after insemination (see Table 1), in accordance with previous reports (Pope et al., 1976; Pennington et al., 1976b) and this level of accuracy is still present 23 days after insemination.

When iodinated progesterone was used for the RIA (rapid incubation followed by polyethylene glycol separation), results could be obtained within $12 \mathrm{~h}$ and the milk values were closely correlated with those obtained in the same samples using tritiated progesterone, and in agreement with those reported by Allen et al. (1980).

In conclusion, by using dextran-coated charcoal and absolute ethanol for the extraction step, followed by RIA with tritiated or iodinated progesterone, we have presented a milk progesterone assay method which is rapid, reliable and can be successfully applied for the diagnosis of pregnancy in cattle.

This research was supported by the CNR project, Biology of Reproduction.

We thank Dr Carlo Staffini, Gandini Farm Palazzo Pignano (Cremona), for supplying the milk samples.

\section{References}

Abraham, G.E., Swerdloff, R., Tulchinsky, D. \& Odell, W.D. (1971) Radioimmunoassay of plasma progesterone. J. clin. Endocr. Metab. 32. 619625 .
Allen, R.M., Redshaw, M.R. \& Holdsworth, R. (1980) A comparison of tritiated and iodinated tracers in the radioimmunoassay of progesterone in cow milk. $J$. Reprod. Fert. 58, 89-93. 
Bulman, D.C. Lamming, G.E. (1976) Radioimmunoassay of progesterone in milk for the diagnosis and treatment of subfertility in dairy cows. J. Endocr. 71 , $52 P$.

Dobson, H. \& Fitzpatrick, R.J. (1976) Clinical application of the progesterone in milk test. Br.vet.J. 132, 538-542.

Donaldson, L.E., Bassett, J.M. \& Thorburn, G.D. (1970) Peripheral plasma progesterone concentration of cows during puberty, oestrous cycles, pregnancy and lactation, and the effect of undernutrition or exogenous oxytocin on progesterone concentration. $J$. Endocr. 48, 599-614.

Erb, R.E., Chew, B.P. \& Keller, H.R. (1977) Relative concentrations of estrogens and progesterone in milk and blood, and excretion of estrogen in urine. $J$. Anim. Sci. 45, 617-626.

Gadsby, J.E., Heap, R.B., Henville, A. \& Laing, J.A. (1974) A semi-automated technique for the estimation of progesterone in cows' milk and its application to pregnancy diagnosis. J. Physiol., Lond. 242, $3 P$.

Ginther, D.J., Nuti, L.C., Garcia, M.C., Wentworth, B.C. \& Tyler, W.J. (1976) Factors affecting progesterone concentration in cows' milk and dairy products. J. Anim. Sci. 42, 155-159.

Glencross, R.G., Munro, I.B., Senior, B.E. \& Pope, G.S. (1973) Concentrations of oestradiol-17 $\beta$, oestrone and progesterone in jugular venous plasma of cows during the oestrous cycle and in early pregnancy. Acta endocr., Copenh. 73, 374-384.

Heap, R.B., Holdsworth, R.J., Gadsby, J.E., Laing, J.A. \& Walters, D.E. (1976) Pregnancy diagnosis in the cow from milk progesterone concentration. Br. vet.J. 132, 445-463.

Hoffmann, B., Günzler, O., Hamburger, R. \& Schmidt, W. (1976) Milk progesterone as a parameter for fertility control in cattle; methodological approaches and present status of application in Germany. $B r$. vet.J. 132, 469-477.

Holness, D.H., Ellison, J.A. \& Wilkins, L.M. (1977) Conception of beef cows in relation to the concentration of progesterone in peripheral blood. $J$. agric. Res. 15, 3-12.

Inaudi, P. \& Genazzani, A.R. (1980) Simultaneous radioimmunoassay of estradiol, progesterone, 17 hydroxyprogesterone, testosterone and androstendione in farm animals. J. Nucl. Med. All. Sci. 24, 3-4.

Inaudi, P., Musarò, M.A., Enne, G., Delrio, G., Lauria, A. \& Genazzani, A.R. (1980) Prospettive dei dosaggi radioimmunologici nello studio della fisiopatologia riproduttiva in zootecnia. $J$. Endocrinol. Invest. 3 Suppl. 2, 19-24.

Pennington, J.A., Spahr, S.L. \& Lodge, J.R. (1976a) Pregnancy diagnosis in dairy cattle by progesterone concentration in milk. J. Dairy Sci. 59, 1528-1531.

Pennington, J.A., Spahr, S.L. \& Lodge, J.R. (1976b) Factors affecting progesterone in milk for pregnancy diagnosis in dairy cattle. Br. vet. J. 132, 487-498.

Pope, G.S., Majzlik, I., Ball, P.J.H. \& Leaver, J.D. (1976) Use of progesterone concentrations in plasma and milk in the diagnosis of pregnancy in domestic cattle. Br. vet. J. 132, 499-506.

Robertson, H.A. \& Sarda, I.R. (1971) A very early pregnancy test for mammals: its application to the cow, ewe and sow. J. Endocr. 49, 407-419.

Schiavo, J.J., Matuszczak, R.L., Oltanacu, E.B. \& Foote, R.H. (1975) Milk progesterone in postpartum and pregnant cows as a monitor of reproductive status. $J$. Dairy Sci. 58, 1713-1718.

Received 8 June 1981 